\title{
Pengelolaan Perkebunan Pisang Cavendish Komersial di Lampung Tengah, Lampung
}

\section{Management of Cavendish Banana Plantations at Plantation Group 3, Central Lampung, Lampung}

\author{
Moh Agus Jamaluddin, Winarso D. Widodo* dan Ketty Suketi
}

Departemen Agronomi dan Hortikultura, Fakultas Pertanian, Institut Pertanian Bogor (Bogor Agricultural University), J1. Meranti, Kampus IPB Darmaga, Bogor 16680, Indonesia Telp. \& Faks.62-251-8629353 e-mail agrohort@apps.ipb.ac.id

*Penulis Korespondensi : wd_widodo@yahoo.com

Disetujui : 8 Mei 2018 / Published Online 2 Januari 2019

\begin{abstract}
The research was conducted to add knowledge, technical experience, job skill, managerial skill, and to learn and analyze the management of plant and fruit care of cavendish banana. The research was held in Central Lampung, Lampung from February to June 2017. The method used to obtain primary data by following and observing the technical activities in the field and interviews. Secondary data are collected from garden reports and archives. The results of the research showed the quality of bananas affected by pruning of leaves, bud injection, bagging, deflowering, defingering, fruit obstacle removing, and installation of fruit insert. Banana diseases that become obstacles at the research location are Black Leaf Streak (BLS) caused by Mycosphaerella fijiensis and banana freckle caused by Guignardia musae. The largest losing fruit for export due to the condition of No Functional Leaf (NFL) caused Banana Freckle. The block with the largest NFL condition was block $27 \mathrm{~A}$ with 7420 plants. The labor index was 2.08 .
\end{abstract}

Keywords: banana, cavendish, plant and fruit care, management

\begin{abstract}
ABSTRAK
Penelitian dilaksanakan untuk menambah wawasan, pengalaman teknis, keterampilan kerja, manajerial, dan secara khusus mempelajari serta menganalisis pengelolaan perawatan tanaman dan buah pisang cavendish. Penelitian dilaksanakan di Lampung pada bulan Februari hingga Juni 2017. Metode yang digunakan untuk mendapat data primer dengan cara mengikuti dan mengamati kegiatan teknis di lapang dan wawancara. Data sekunder diperoleh dari laporan dan arsip kebun. Hasil penelitian menunjukkan kualitas buah pisang dipengaruhi pemangkasan daun, penyuntikan jantung, pembrongsongan, pembuangan bunga, pembuangan buah, pembuangan penghalang buah, dan pemasangan sekat buah. Penyakit pisang yang menjadi kendala di lokasi penelitian adalah Black Leaf Streak (BLS) yang disebabkan oleh Mycosphaerella fijiensis dan banana freckle yang disebabkan oleh Guignardia musae. Kehilangan buah ekspor terbesar karena kondisi No Functional Leaf (NFL) karena Banana Freckle. Blok dengan kondisi NFL terbesar adalah blok 27A dengan jumlah 7420 tanaman. Indeks tenaga kerja sebesar 2.08.
\end{abstract}

Kata kunci : cavendish, pengelolaan, perawatan tanaman dan buah, pisang 


\section{PENDAHULUAN}

Buah pisang banyak dikonsumsi karena rasanya yang enak dan kandungan gizi yang tinggi. Pisang sangat baik untuk dikonsumsi karena memberikan cadangan energi yang cepat tersedia bagi tubuh dan merupakan sumber vitamin C dan B6 yang baik (FAO, 2016). Konsumsi total pisang pada tahun 2013 mencapai $5.63 \mathrm{~kg} / \mathrm{kapita} /$ tahun (Pusdatintan, 2014). Hingga saat ini peningkatan produksi dan kualitas pisang terus diupayakan untuk memenuhi kebutuhan konsumen. Pada tahun 2015 terjadi kenaikan produksi pisang sebesar $6.36 \%$ dari tahun 2014 . Produksi pisang pada tahun 2014 sebesar 6862558 ton dan tahun 2015 sebesar 7299266 ton (BPS, 2016).

Nilai ekspor pisang Indonesia masih rendah apabila dibandingkan negara ASEAN lainnya. Indonesia berada di urutan kelima dengan kontribusi terhadap volume ekspor pisang Asia Tenggara hanya sebesar $0.06 \%$. Negara eksportir pisang terbesar di Asia Tenggara adalah Filipina yang menyumbang lebih dari $95 \%$ volume ekspor pisang ASEAN tahun 2007-2011. Hal ini disebabkan varietas yang ditanam di Indonesia sangat beragam, sedangkan pasar internasional lebih menyukai pisang dari kelompok Cavendish (Kementan, 2014). Pisang Cavendish merupakan salah satu kultivar pisang yang komersial di dunia selain Baby banana dan Monkey (PKHT IPB, 2012). Pengembangan kultivar kelompok Cavendish di Indonesia menghadapi kendala serangan penyakit layu Fusarium (Deptan, 2005).

Produksi pisang dengan sistem pertanian komersial masih belum populer di Indonesia. Sebagian besar pertanaman pisang rakyat ditanam di pekarangan sebagai tanaman campuran dengan tanaman lain atau tumpang sari atau di lahan tegalan (Ditjen Horti, 2016). Hal ini menyebabkan masih sedikitnya ekspor pisang Indonesia karena kualitas yang kurang baik. Pengusahaan pisang skala perkebunan diperlukan untuk mendukung pemenuhan kebutuhan pisang nasional dan ekspor.

Kualitas buah pisang sering ditentukan melalui tampilan kulitnya yang mulus tanpa cacat. Kulit pisang yang mulus dapat diperoleh melalui teknik budidaya dan pascapanen yang baik. Menurut Ditjen Horti (2016) rangkaian budidaya yang baik dan benar adalah dari pemilihan lokasi, pemilihan bibit dan varietas, pemeliharaan, pemupukan, pengendalian hama dan penyakit serta pemanenan.

Tujuan penelitian menguraikan perawatan pertanaman pisang Cavendish skala perkebunan.

\section{BAHAN DAN METODE}

Kegiatan penelitian ini dilaksanakan di Plantation Group 3, Desa Gunung Batin Baru, Kecamatan Terusan Nunyai, Kabupaten Lampung Tengah, Provinsi Lampung. Penelitian dilakukan selama 4 bulan dari bulan Februari 2017 sampai dengan bulan Juni 2017.

Metode pelaksanaan penelitian dengan cara melakukan praktik kerja sebagai karyawan harian lepas (KHL) selama kurang lebih dua bulan, sebagai pendamping mandor satu bulan, dan pendamping kepala seksi satu bulan untuk memperoleh data primer. Praktik kerja tidak dilakukan secara kontinu dan jadwal sesuai arahan pembimbing lapang. Data sekunder diperoleh dari laporan bulanan, laporan tahunan, dan arsip-arsip kebun.

Data primer diperoleh dengan melakukan beberapa pekerjaan teknis di lapangan, wawancara, diskusi dengan staf dan karyawan perkebunan serta menghitung prestasi kerja beberapa pekerja. Hasil kegiatan lapangan pada pemeliharaan yang dikumpulkan sebagai data primer seperti :

1. Pekerjaan perawatan yang menentukan kualitas buah, hal yang diamati yaitu pekerjaaan yang ada di perawatan tanaman dan buah serta pekerjaan perawatan apa saja yang diterapkan oleh perusahaan yang dapat menentukan kualitas buah pisang supaya dapat diekspor.

2. Pemupukan, hal yang diamati yaitu jenis, realisasi ketepatan waktu dan dosis pemupukan serta dasar penentuannya. Data diperoleh dari rata-rata 10 tenaga kerja dari 3 kali ulangan. Pengamatan dilakukan selama 30 minggu di 3 blok.

3. Penanganan organisme pengganggu tanaman (OPT), pengamatan dilakukan untuk mengetahui kegiatan yang berkaitan dengan penanganan OPT, bahan aktif pestisida, konsentrasi bahan aktif, tempat, cara aplikasi, dan kendala yang ada di kebun.

4. Kehilangan populasi (losing), data yang diperoleh adalah faktor yang membuat berkurangnya populasi tanaman pisang, jumlah kehilangan dari setiap faktor, dan persentase kehilangannya. Pengamatan dilakukan selama 6 minggu pada 5 blok yang memasuki masa panen dari 3 bulan periode pemanenan.

5. Manajerial kebun, Informasi yang didapatkan adalah organisasi perawatan, penentuan kebutuhan tenaga kerja dan rotasi kegiatan perawatan tanaman dan buah serta indeks tenaga kerja (ITK). 
Data sekunder diperoleh dari arsip data perusahaan tentang laporan harian, laporan bulanan, laporan tahunan, serta arsip kebun. Kondisi dan kegiatan umum di perkebunan memerlukan data seperti : peta kebun, curah hujan, kondisi lahan dan tanaman, produksi dan produktivitas kebun serta struktur organisasi. Data untuk aspek khusus pemeliharaan tanaman diperlukan data sekunder seperti : kondisi lahan, klon tanaman, jumlah tanaman, umur tanaman pada setiap blok, hasil pekerjaan. Data tersebut dibutuhkan untuk menganalisis kegiatan yang dilakukan, secara deskriptif dan dibandingkan dengan sumber pustaka yang baku.

Data dan informasi yang telah terkumpul kemudian dianalisis dengan perhitungan matematika sederhana yang meliputi nilai ratarata dan persentase. Hasil yang didapatkan kemudian dibandingkan dengan standar kerja dan SOP yang dimiliki perusahaan serta pustaka tentang standar budidaya tanaman pisang.

\section{HASIL DAN PEMBAHASAN}

\section{Perawatan untuk Kualitas Buah Pisang}

Perawatan tanaman pisang Cavendish di Plantation Group 3 terdiri dari dua perawatan yaitu perawatan tanaman dan perawatan buah. Perawatan tanaman berfokus pada kesehatan tanaman dan perawatan buah menjaga kualitas buah tetap baik. Kedua perawatan ini bertujuan agar produk yang dihasilkan berupa buah pisang segar dapat diekspor dengan kuantitas maksimal. Kedua perawatan ini yang membedakan perawatan pisang yang dilakukan oleh masyarakat dengan perkebunan. Perawatan yang dapat menentukan kualitas buah pisang terdiri atas:

\section{Pemangkasan Daun.}

Terdapat dua perlakuan dalam pemangkasan daun yaitu pembuangan daun sebagian (trimming) dan pembuangan daun penuh (cutting). Eksekusi dari pekerja apakah memilih trimming atau cutting dapat mempengaruhi kualitas tanaman dan buah pada waktu panen. Pengalaman kerja dibutuhkan untuk pekerjaan ini. Pekerja dituntut bekerja cepat dan berkualitas karena dengan target 3000 pohon bukan jumlah yang sedikit. Rata rata prestasi tenaga kerja adalah sebesar 1500 pohon. Target 3000 pohon ini bukan berarti pekerja harus melakukan pemangkasan daun di 3000 pohon yang ditemui. Pengertian yang sebenarnya adalah dari 3000 pohon yang ditemui pemangkasan daun hanya dilakukan pada pohon yang memang memerlukan pemangkasan. Kriteria daun yang dipangkas seperti daun terserang hama dan penyakit, daun kering, daun yang pelepahnya patah, dan daun yang bergesekan dengan buah. Pengertian ini harus disampaikan ke pekerja dengan jelas supaya tidak melakukan kelebihan pemangkasan (over cutting). Alasan tersebut yang menjadi salah satu penyebab pekerja belum mencapai target.

Pekerja pemangkasan daun kebanyakan adalah pekerja baru oleh karenanya pengetahuan tentang penyakit pisang masih sedikit. Pelatihan kepada pekerja secara berkala mengenai jenis penyakit dan cara melakukan pemangkasan daun yang baik dapat dilakukan supaya keterampilan pekerja bertambah. Hasil pekerjaan pemangkasan daun yang baik dapat mempengaruhi rotasi kerja dan kualitas buah pisang. Kualitas buah pisang sangat ditentukan oleh baik tidaknya daun yaitu jumlah dari daun sehat. Standar jumlah daun pisang sehat sampai panen yang ditentukan oleh perusahaan adalah 5 daun supaya pisang dapat diekspor. Apabila daunnya kurang dari 5 dikhawatirkan pisang akan matang bahkan busuk diperjalanan karena pisang yang ketika dipanen jumlah daunnya kurang dari 5, buahnya akan cepat masak. Kondisi pisang yang daunnya kurang dari 5 istilah kebunnya adalah no functional leaf (NFL).

\section{Penyuntikan Jantung Pisang}

Penyuntikan jantung pisang merupakan langkah awal untuk melindungi buah dari serangga dengan cara menyuntikan larutan insektisida. Penyuntikan jantung pisang dilakukan pada pohon yang sudah muncul jantung dengan persentase kemunculan jantung antara 50-100\% dan belum melengkung ke bawah (bending). Apabila penyuntikan dilakukan pada saat jantung pisang bending akan mengakibatkan jantung busuk. Jantung yang busuk akan menghasilkan jumlah sisir yang lebih sedikit.

Jantung pisang yang telah disuntik dengan baik memiliki ciri warna seludang buahnya (bracts) ungu gelap dan kulit buahnya terasa halus ketika diraba. Sedangkan jantung yang penyuntikannya kurang baik ditandakan dengan bracts berwarna lebih terang dan kulit buahnya terasa kasar ketika diraba.

Penyuntikan dilakukan pada seperempat bagian dari ujung jantung dengan sudut kemiringan berkisar $45^{\circ}$. Hal ini dilakukan untuk menghindari tertancapnya buah oleh jarum suntik. Sudut penyuntikan yang tepat akan membuat penyebaran larutan di dalam jantung pisang merata. Lama penyuntikan sekitar 11 detik untuk jantung yang berukuran besar. Hitungan ini dapat berubah apabila ditemukan jantung dengan ukuran lebih kecil. Penilaian ini bergantung pada pengamatan dan pengalaman tenaga kerja. 
Kendala pada penyuntikan jantung pisang adalah pengalaman tenaga kerja yang masih kurang. Hal ini karena masa kerja yang kurang dari 6 bulan. Kendala lain adalah terlewatnya penyuntikan jantung karena telah bending. Penyebabnya adalah terkadang pengamatan pekerja kurang jeli sehingga jantung yang telah muncul terlewat untuk disuntik. Pisang yang tidak disuntik tetap dipelihara sampai panen diharapkan kualitasnya tidak berbeda dengan yang disuntik dan masih dapat dijual.

\section{Pembrongsongan (bagging)}

Pembrongsongan adalah kegiatan pembungkusan tandan pisang yang telah bending dan 2 seludang sisir terbuka. Pembrongsongan dilakukan untuk melindungi buah pisang dari serangga dan jamur selama pengisian buah. Selain melindungi dari serangga dan jamur juga memperkecil gesekan antara buah dengan pelepah pisang. Hal ini sesuai dengan hasil penelitian Bahrir (2012) yang menyebutkan perlakuan pembungkusan tandan pisang menekan serangan hama pada kulit pisang tanduk. Pembungkus yang digunakan oleh perusahaan adalah kertas khusus (paper bag) yang memiliki sifat tahan air dan spunbond atau istilah kebunnya hygro. Kertas pembungkus ini diimpor dari negara Taiwan. Pertimbangan memakai kertas adalah untuk mengurangi penggunaan plastik.

Penggunaan paper bag dan hygro sekaligus membuat pekerjaan lambat. Akibatnya prestasi tenaga kerja menurun karena harus memasang kedua bahan tersebut. Prestasi yang menurun berakibat pada telatnya pembrongsongan blok lain. Keserempakan muncul jantung yang rendah membuat pekerja harus cermat mencari tandan yang siap dibungkus. Saat periode awal muncul jantung sulit bagi tenaga kerja untuk mencapai standar perusahaan. Sebab, ketersediaan buah masih sedikit per harinya. Pada saat ini perhitungan prestasi pekerja bukan berupa jumlah tanaman akan tetapi luasan yang telah dikerjakan atau istilah kebunnya standar cover blok.

Menurut penulis penggunaan paper bag tanpa adanya tambahan hygro sudah cukup untuk mencegah serangan hama dan jamur. Penulis beranggapan selama paper bag tidak mengalami cacat sobek kualitas dari kulit buah pisang dapat dipertahankan.

\section{Pembuangan Bunga, Buah, dan Penghalang Buah (DDF)}

Pembuangan bunga dilakukan untuk menghindari berkembangnya jamur pada bunga yang busuk. Selain itu menurut Ngatoif (2011) secara umum pemotongan bunga jantan 3 minggu setelah berbunga meningkatkan panjang dan lingkar buah pisang. Pembuangan buah adalah kegiatan pembuangan jari buah pisang (finger) untuk mengatur posisi dan bentuk buah. Tujuan lainnya adalah menghilangkan jari palsu yang berpotensi tidak berkembang menjadi buah. Penghalang buah yang dibuang adalah bracts yang telah lepas dan pelepah daun yang berpotensi bergesekan dengan buah.

Kendala dari pekerjaan pembuangan bunga adalah pada saat pembuangan bunga lilin atau bunga plastik. Bunga lilin memiliki sifat lebih keras dibanding bunga biasa sehingga susah di hilangkan. Bunga lilin yang jumlahnya banyak dapat menghambat pekerjaan sehingga prestasi tenaga kerja dapat menurun. Pembuangan bunga dilakukan ketika buah masih berumur muda. Pembuangan bunga ketika masih muda membuat pisang mengeluarkan banyak getah. Getah yang menetes atau terkena tangan dapat menjadi lateks yang menempel pada kulit pisang. Perlu adanya kesadaran diri pada pekerja untuk senantiasa mengelap tangan ketika melakukan pembuangan bunga dan jari buah serta memasang penghalang getah.

Getah yang menetes perlu dicegah dengan cara memasang penghalang supaya tidak mengenai buah di bawahnya. Penghalang getah pada kegiatan DDF ada dua bahan yaitu potongan paper bag dan tisu. Penggunaan paper bag diterapkan pada buah yang masih muda. Penggunaan tisu untuk buah yang posisinya telah jelentar atau melengkung ke atas dan pada saat pembuangan jari buah pisang. Pada penerapannya sebaiknya penggunaan tisu di lakukan secara efisien dan bahkan dikurangi. Caranya adalah dengan melakukan DDF pada tandan yang masih muda dan jangan sampai terlewat sehingga buah telah melengkung $k e$ atas. Pengurangan penggunaan tisu tentu akan menekan biaya serta lebih ramah lingkungan.

\section{Pemasangan Sekat Buah}

Kualitas kulit buah adalah faktor utama yang mempengaruhi harga jual buah pisang. Kulit buah yang mulus dapat meningkatkan harga jual buah pisang. Kemulusan kulit menjadi patokan untuk menentukan kelas dari produk pisang yang dijual oleh perusahaan. Banyaknya pisang berkulit mulus akan menghasilkan pisang kelas premium yang lebih banyak. Usaha perkebunan pisang Cavendish dapat diibaratkan menjual kualitas kulit buah pisang. Perawatan buah sangatlah penting untuk menjaga hal tersebut. Selain pembrongsongan pemasangan sekat adalah salah satu cara untuk menjaga kualitas kulit buah pisang. Sekat yang dipasang berupa plastik atau 
Tabel 1. Jadwal dan dosis pupuk per satu siklus tanaman

\begin{tabular}{lccccccc}
\hline \multirow{2}{*}{ Umur (BST) } & \multicolumn{7}{c}{ Pupuk (kg/tanaman) } \\
\cline { 2 - 8 } & Organik & Urea & TSP & KCl & Kieserit & $\mathrm{ZnSO}_{4}$ & Dolomit \\
\hline 0 & 15 & - & - & - & - & - & $2.080^{*}$ \\
1 & - & 0.050 & - & 0.050 & - & 0.047 & - \\
2 & - & 0.100 & 0.053 & 0.100 & - & - & $0.750^{*}$ \\
3 & - & - & - & - & 0.320 & - & - \\
4 & - & 0.100 & - & 0.125 & - & - & $0.400^{*}$ \\
$5 \mathrm{SC}$ & - & 0.100 & - & 0.150 & - & - & - \\
$6 \mathrm{SC}$ & - & 0.100 & 0.053 & 0.150 & - & - & - \\
$7 \mathrm{SC}$ & - & 0.075 & - & 0.125 & 0.320 & - & - \\
$8 \mathrm{SC}$ & - & 0.075 & - & 0.100 & - & - & - \\
$9 \mathrm{SC}$ & - & 0.075 & 0.053 & 0.100 & - & - & - \\
$10 \mathrm{SC}$ & - & 0.075 & - & 0.100 & - & 0.035 & - \\
\hline KC
\end{tabular}

Keterangan : Kondisional, BST: bulan setelah tanam, SC: anakan pertama, Sumber : Kantor Divisi Pisang PG3 2017 (diolah)

busa akan melindungi buah dari gesekan antar buah.

Kendala dalam pelaksanaan pemasangan sekat adalah harus memasang satu per satu sekat pada tiap sisir pisang. Sehingga pekerjaan ini membutuhkan kesabaran lebih dan membuat prestasi pekerja masih dibawah standar. Plastik sekat yang digunakan terkadang licin yang membuat pekerja susah untuk memasangnya. Busa yang digunakan ketika penulis melakukan penelitian belum sesuai. Busa yang digunakan ukurannya terlalu besar. Hal ini membuat pekerjaan yang dilakukan terkesan berantakan. Kendala lain yang membuat pekerjaan menjadi lama adalah pekerja harus membawa tangga bambu untuk memasang sekat. Tangga ini dibawa oleh pekerja ke setiap pohon yang akan dipasang sekat.

Saran untuk perusahaan, dalam penggunaan busa sebaiknya ukurannya disesuaikan. Lebih baik dilakukan uji efektifitas antara penggunaan plastik dan busa. Hasil dari uji ini nantinya dapat digunakan sebagai pertimbangan pemakaian bahan sekat. Biaya pengadaan juga dapat dijadikan bahan perbandingan.

\section{Pemupukan Tanaman}

Pemupukan merupakan bagian penting dalam budidaya tanaman. Budidaya tanaman yang berlangsung lama dapat menyebabkan kandungan unsur hara pada tanah menurun. Pemupukan menjadi faktor pendorong pertumbuhan tanaman pisang untuk mencukupi kebutuhan haranya. Respon pemupukan tanaman pisang lebih cepat apabila dibandingkan tanaman tahunan. Pemupukan sering berdasarkan azaz 5 tepat yaitu tepat jenis, tepat dosis, tepat waktu, tepat cara, dan tepat tempat. Pupuk yang digunakan adalah pupuk anorganik dan beberapa jenis kapur. Dosis pupuk ditentukan oleh tim riset perusahaan. Jadwal pemupukan telah dibuat ketika pisang mulai ditanam. Cara aplikasi pupuk adalah ditebar langsung melingkar dengan jarak $30 \mathrm{~cm}$ dari batang dan maksimal seluas tajuk. Sasaran pemupukan pada bulan kelima adalah anakan pertama karena sudah mulai dipelihara. Kebutuhan pupuk tanaman pisang Cavendish selama satu siklus tanaman di PG3 disajikan pada Tabel 1.

Pemberian pupuk Urea, TSP, dan $\mathrm{KCl}$ adalah untuk memenuhi kebutuhan hara makro bagi tanaman pisang. Hara makro adalah unsur hara yang dibutuhkan tanaman dalam jumlah besar. Pemberian pupuk Urea dan $\mathrm{KCl}$ dilakukan rata rata satu bulan sekali, sementara TSP tiga bulan sekali. Aplikasi dolomit sebelum tanam diberikan pada saat pengolahan tanah. Dosis dolomit yang diberikan paling besar yaitu $2.08 \mathrm{~kg}$. Pemberian dolomit ini bersifat kondisional kebun. Bersifat kondisional karena ada pertimbangan nilai derajat kemasaman $(\mathrm{pH})$ tanah. Apabila $\mathrm{pH}$ tanah nilainya $\geq 6$ maka tidak perlu dilakukan aplikasi dolomit. Berikut pemberian dolomit disajikan pada Tabel 2.

Tabel 2. Rekomendasi dosis dolomit di Plantation Group 3

\begin{tabular}{lcc}
\hline \multirow{2}{*}{ pH Tanah } & \multicolumn{2}{c}{ Dosis $\left(\right.$ ton $\left.\mathrm{ha}^{-1}\right)$} \\
\cline { 2 - 3 } & Dolomit & Kalsit \\
\hline Sebelum tanam & & \\
$<4.5$ & - & 4.1 \\
$\quad 4.5-4.9$ & 5.0 & - \\
$5.0-5.5$ & 2.4 & - \\
$5.6-5.9$ & 1.8 & - \\
$\quad \geq 6.0$ & 0 & - \\
Setelah tanam & & \\
$\quad<6.0(2 \mathrm{BST})$ & 1.8 & - \\
$<6.0($ BBST) & 1.0 & - \\
$\geq 6.0$ & - & - \\
\hline
\end{tabular}

Sumber : Kantor Riset PT NTF 2017 
Penggunaan kalsit ditujukan untuk mempercepat kenaikan $\mathrm{pH}$ tanah dan memperkecil dosis dolomit. Apabila tidak memakai kalsit dosis dolomit yang diberikan mencapai 7.4 ton $\mathrm{ha}^{-1}$. Pemberian dolomit setelah tanam dilakukan pada 2 BST dan 4 BST apabila $\mathrm{pH}$ kurang dari 6. Menggunakan pertimbangan ekonomi, penggunaan pupuk dan tenaga kerja pemupukan harus dilakukan secara efisien. Berikut data realisasi waktu dan dosis dari blok 12B, 22B, dan 20B disajikan pada Tabel 3 dan Tabel 4.

Tabel 3. Realisasi waktu pemupukan sampai umur 30 minggu

\begin{tabular}{lcrrr}
\hline Jenis & Tepat & $\begin{array}{r}\text { Tidak } \\
\text { Tepat }\end{array}$ & $\begin{array}{r}\text { Total } \\
\text { Pemupukan }\end{array}$ & $\begin{array}{r}\text { Persentase } \\
\text { Ketepatan }\end{array}$ \\
\cline { 2 - 5 } & \multicolumn{2}{c}{$\ldots \ldots \ldots \ldots$ kali } & $\ldots \ldots \ldots \ldots$ & $(\%)$ \\
\hline Urea & 3 & 18 & 21 & 14.3 \\
TSP & 0 & 9 & 9 & 0 \\
KCl & 4 & 17 & 21 & 19 \\
\hline
\end{tabular}

Berdasarkan tabel 3 di atas dapat dijelaskan bahwa ketepatan waktu pemupukan jauh dari jadwal yang telah dibuat oleh perusahaan. Ketepatan waktu aplikasi Urea dan $\mathrm{KCl}$ hanya $14.3 \%$ dan 19\%. Sedangkan untuk TSP dari 9 kali aplikasi tidak ada yang sesuai jadwal. Ketepatan aplikasi pupuk dapat dipengaruhi oleh faktor bahan baku, jumlah tenaga kerja, dan akses jalan kebun. Bahan baku berupa pupuk yang diaplikasikan apabila pengadaannya telat dapat menunda pekerjaan. Perhitungan tenaga kerja jika menggunakan pertimbangan sesuai jadwal membuat pekerjaan terhambat. Hal ini karena apabila pemupukan telat pekerjaan akan menumpuk yang akhirnya tidak terselesaikan. Akses jalan kebun yang rusak membuat kendaraan (unit) pengangkut pupuk susah masuk ke kebun. Akses jalan rusak dapat disebabkan oleh cuaca yaitu hujan.

Tabel 4. Realisasi dosis pemupukan sampai umur 30 minggu

\begin{tabular}{lcccc}
\hline \multirow{2}{*}{$\begin{array}{l}\text { Jenis } \\
\text { Pupuk }\end{array}$} & $\begin{array}{c}\text { Dosis } \\
\text { Rekomendasi }\end{array}$ & \multicolumn{3}{c}{$\begin{array}{c}\text { Realisasi Dosis } \\
(\mathrm{g} / \text { tanaman })\end{array}$} \\
\cline { 2 - 5 } & $(\mathrm{g} /$ tanaman $)$ & Blok & Blok & Blok \\
& & $12 \mathrm{~B}$ & $20 \mathrm{~B}$ & $22 \mathrm{~B}$ \\
\hline Urea & 600 & 551 & 554 & 550 \\
TSP & 159 & 158 & 106 & 159 \\
KCl & 800 & 702 & 730 & 710 \\
\hline
\end{tabular}

Tabel 4 menunjukkan bahwa total realisasi pupuk masih di bawah standar perusahaan. Dosis pupuk Urea dan $\mathrm{KCl}$ pada 3 blok contoh di bawah standar. Sedangkan pupuk TSP pada blok 12B dan 22B telah sesuai rekomendasi perusahaan. Penambahan dan pengurangan dosis pemupukan dapat dilakukan apabila pengamatan visual menunjukkan pertumbuhan tanaman pisang telah sesuai harapan. Penambahan pupuk tidak selalu dapat meningkatkan pertumbuhan tanaman. Karena ada ambang maksimal yang tidak menunjukan perbedaan pemupukan bahkan dapat menyebabkan keracunan pupuk. Sebaliknya apabila kekurangan pupuk akan menyebabkan defisiensi unsur hara pada tanaman.

Kendala umum dari kegiatan pemupukan adalah keterlambatan pupuk, jumlah tenaga kerja yang kurang, dan kurangnya pengawasan. Keterlambatan pupuk dapat disebabkan pengadaan pupuk yang terlambat karena stok di distributor habis. Keterlambatan pupuk juga dapat disebabkan akses jalan yang rusak atau pengadaan unit telat. Pupuk yang terlambat masuk ke blok dapat berpengaruh pada tidak efektifnya penggunaan tenaga kerja, karena harus dialihkan ke pekerjaan lain selama menunggu kedatangan pupuk. Pengawasan harus dilakukan supaya prosedur dilakukan dengan benar dan menghindari pupuk tercecer.

\section{Penanganan Organisme Pengganggu Tanaman (OPT)}

Kegiatan yang berkaitan dengan penanganan OPT adalah penyemprotan herbisida, penyemprotan insektisida, dan suntik jantung. Keadaan kebun yang bersih dari gulma, jamur, dan hama dapat mempengaruhi pertumbuhan tanaman pisang. Hama dan penyakit dapat menurunkan jumlah populasi tanaman. Penanganan yang terlambat dapat berakibat fatal pada hasil panen. Hasil panen yang turun menyebabkan pendapatan perusahaan turun.

Herbisida dan insektisida merupakan bahan kimia yang memberi dampak pada tubuh manusia. Penggunaannya harus sesuai dengan ketentuan penggunaan produk. Penggunaan sembarangan dapat menyebabkan iritasi dan keracunan yang dapat berakhir pada kematian. Dibutuhkan alat pelindung diri (APD) pada saat penggunaan bahan kimia tersebut. Pekerja yang melakukan kegiatan pengendalian OPT harus disiplin dalam memakai APD. Berdasarkan observasi yang telah dilakukan oleh penulis, alat pelindung diri (APD) yang digunakan oleh pekerja masih kurang. APD yang digunakan oleh pekerja hanya berupa boot, masker kain, dan pakaian kerja biasa. Setelah penulis mengkonfirmasi kepihak perusahaan APD yang sesuai seperti masker kimia dan pakaian khusus penyemprotan masih dalam pengadaan.

Bahan aktif herbisida yang digunakan perusahaan merupakan bahan aktif yang diperbolehkan oleh Kementerian Pertanian Republik Indonesia untuk pertanian dan 
kehutanan. Bahan aktif berupa glufosinat digunakan untuk pengendalian gulma diseluruh wilayah kebun. Bahan aktif paraquat hanya digunakan untuk pengendalian gulma pada jalan dan pinggiran lebung (Tabel 5).

Tabel 5. Penggunaan pestisida untuk pengendalian organisme pengganggu

\begin{tabular}{|c|c|c|c|}
\hline Kegiatan & Bahan Aktif & $\begin{array}{c}\text { Konsentrasi } \\
\left(\mathrm{ml} \mathrm{l}^{-1}\right)\end{array}$ & Sasaran/Tempat \\
\hline $\begin{array}{l}\text { Penyemprotan } \\
\text { herbisida }\end{array}$ & $\begin{array}{l}\text { Ammonium } \\
\text { glufosinat }\end{array}$ & 5 & $\begin{array}{l}\text { gulma/baris } \\
\text { tanaman pisang }\end{array}$ \\
\hline $\begin{array}{l}\text { Penyemprotan } \\
\text { insektisida }\end{array}$ & Klorpirifos & 1 & $\begin{array}{l}\text { serangga/daun, } \\
\text { batang tanaman } \\
\text { pisang }\end{array}$ \\
\hline $\begin{array}{l}\text { Penyuntikan } \\
\text { jantung pisang }\end{array}$ & $\begin{array}{l}\text { Metomil } \\
\text { Klorpirifos }\end{array}$ & $\begin{array}{l}1 \\
3\end{array}$ & $\begin{array}{l}\text { serangga/jantung } \\
\text { pisang } \\
\text { serangga/jantung } \\
\text { pisang }\end{array}$ \\
\hline
\end{tabular}

Waktu pengendalian OPT bersifat tentatif atau kondisional kebun. Pengendalian gulma di blok yang tanaman pisangnya berumur muda sekitar 1-4 bulan dilakukan secara intensif. Berbeda dengan blok yang tanaman pisangnya sudah berumur lebih dari 4 bulan pengendalian gulma dilakukan rata-rata 2 minggu sekali. Insektisida digunakan untuk mengendalikan serangga berupa kutu kebul pada tanaman pisang muda dan semut pada tanaman pisang dewasa. Insektisida juga digunakan untuk melindungi calon buah yaitu jantung pisang dari serangan serangga.

Prestasi tenaga kerja masih dibawah standar yang ditetapkan oleh perusahaan dan prestasi kerja penulis masih dibawah tenaga kerja. Prestasi penulis didapatkan dengan cara sampling dengan batasan waktu selama 1 jam. Perolehan ini dibandingkan dengan rata-rata per jam dari tenaga kerja. Penulis tidak dapat melakukan pekerjaan semprot gulma secara penuh. Hal ini dikarenakan keterbatasan alat semprot yang ada. Selama ini alat semprot yang digunakan adalah milik pekerja sendiri. Perusahaan belum membuat kebijakan pengadaan alat untuk penyemprotan gulma maupun insek. Penulis menyarankan supaya perusahaan dapat melakukan pengadaan alat semprot. Alasannya adalah dengan pengadaan alat semprot dari perusahaan nantinya kualitas semprot akan lebih seragam dan mudah untuk melakukan perhitungan efektifitas kerja. Selama ini pekerja menggunakan alat semprot dengan merek dan tipe yang berbeda-beda dan tidak hanya itu penggunaan nozzle juga tidak ada standarisasi.

\section{Kehilangan Populasi Ekspor (Losing)}

Penyebab populasi tanaman pisang beragam diantaranya serangan hama, terjangkit penyakit tanaman, cuaca, kesalahan data, aktivitas manusia, dan telat panen. Hama dan penyakit tanaman merupakan masalah utama dalam budidaya tanaman. Penanganannya dibutuhkan respon cepat sebelum menyebar keseluruh kebun. Cuaca yang ekstrim seperti panas dan angin kencang dapat menyebabkan kekeringan dan pisang roboh. Kesalahan rekap data akan membuat populasi seakan menurun dan membingungkan. Perusahaan perlu merekap data secara periodik. Rekap data populasi penting dilakukan karena berkaitan dengan taksasi produksi. Data populasi yang benar akan menentukan target panen nantinya. Pemanenan yang telat menyebabkan buah tertinggal dan tidak terpanen akan merugikan perusahaan. Kehilangan populasi buah ekspor mingguan selama 6 minggu dari bulan April hingga minggu kedua Mei pada 5 sampel blok disebabkan oleh umur tua (over age) dan kondisi no functional leaf (NFL). Periode pemanenan untuk satu blok kurang lebih selama 3 bulan. Pengamatan yang dilakukan penulis bukan hasil keseluruhan satu periode panen. Berikut data hasil pengamatan losing selama 6 minggu disajikan pada Tabel 6.

Tabel 6. Hasil pengamatan losing akibat over age dan no functional leaf

\begin{tabular}{|c|c|c|c|c|}
\hline \multicolumn{5}{|c|}{ Blok Klon Populasi Awa } \\
\hline 20B CJ30 & 23397 & 228 & 0 & 23169 \\
\hline $21 \mathrm{~A}$ CJ30 & 29238 & 267 & 20 & 28951 \\
\hline 22B CJ30 & 46566 & 356 & 40 & 46170 \\
\hline 12B CJ40 & 37468 & 506 & 0 & 36962 \\
\hline 27A CJ30 & 39480 & 233 & 7360 & 31887 \\
\hline Total & 176149 & 1590 & 7420 & 167139 \\
\hline
\end{tabular}

Berdasarkan Tabel 6 diketahui bahwa penyebab losing terbesar adalah NFL yang berjumlah 7420 tanaman atau $4.2 \%$ dari populasi awal. Jumlah losing ini apabila dikonversi kedalam luasan adalah 3.09 ha dengan asumsi populasi per hektar 2400 (tanaman pertama). Losing akibat over age sebesar 1.590 tanaman atau 0.66 ha dan $0.9 \%$ dari total populasi. Blok yang memiliki buah umur tua paling banyak adalah blok 12B dan blok yang memiliki masalah NFL paling banyak adalah blok 27A.

Losing sebesar ini dapat memberikan dampak penurunan kapasitas ekspor perusahaan. Meski dapat dipanen, tanaman umur tua dan NFL tidak dapat diekspor karena khawatir akan matang selama perjalanan. Jika tidak ada stok cadangan buah di kebun tentu menjadi masalah pada pemenuhan permintaan ekspor. Alternatif yang diambil untuk tanaman umur tua dan NFL adalah penjualannya untuk pasar lokal. Penurunan penjualan ekspor secara signifikan menurunkan pendapatan perusahaan, karena perbedaan harga jual. 
Buah berumur tua adalah akibat dari ketinggalan panen. Perencanaan dan realisasi panen yang tidak sejalan seringkali menyebabkan buah ketinggalan panen pada suatu blok. Sistem kerja panen adalah berpindah pindah, mengutamakan blok yang memiliki buah siap panen terbanyak. Sehingga blok yang telah dipanen dan ada yang sisa akan menjadikan umur buah semakin tua. NFL adalah akibat dari Banana Freckle. Banana Freckle disebabkan oleh jamur Guignardia musae yang menutupi permukaan daun pisang yang menyebabkan daun mengering. Banana Freckle akan menurunkan jumlah daun pada tanaman pisang dan menyebabkan pengisian buah tidak maksimal. Jumlah daun yang sedikit membuat buah cepat matang. Banana Freckle menjadi masalah penting di perkebunan pisang Cavendish. Ini merupakan suatu tantangan dan peluang bagi tim riset dan pemulia tanaman untuk menemukan klon baru yang lebih tahan terhadap serangan banana freckle.

\section{Organisasi Perawatan}

Pembagian kerja sangat penting dalam perusahaan tak terkecuali bidang perkebunan. Pekerjaan terselesaikan dengan baik dan cepat dengan spesialisasi pekerjaan. Perawatan pisang Cavendish di PG3 terdiri atas perawatan tanaman dan perawatan buah. Masing masing perawatan dipimpin oleh beberapa kasi sesuai kebutuhan. Perawatan tanaman dipimpin oleh empat orang kasi yang dibagi berdasarkan wilayah dan biasa disebut kepala wilayah (kawil). Sedangkan perawatan buah dipimpin oleh dua kasi yang dibagi berdasarkan divisi yaitu divisi 5 dan 6 . Kasi didalam pekerjaannya dibantu oleh beberapa mandor yang membawahi tenaga kerja (TK) dengan jumlah sesuai kegiatan yang ada. Perhitungan kebutuhan tenaga kerja pada satu kegiatan berdasarkan luasan wilayah kerja, waktu penyelesaian kegiatan yang diinginkan (cycle), dan standar kapasitas kerja dari kegiatan tersebut.

Jumlah TK $=\frac{\text { Luas wilayah kerja (ha) }}{\text { SOP kapasitas kerja (ha/hari) } \times \text { waktu penyelesaian (hari) }}$

Sebagai contoh perhitungan kebutuhan TK pada kegiatan penyemprotan herbisida yang standarnya setiap pekerja menyelesaikan luasan 1 ha/hari. Asumsi waktu penyelesaian adalah 12 hari dengan luas wilayah kerja 300 ha. Berdasarkan rumus di atas jumlah TK yang dibutuhkan adalah sebanyak 25 orang. Indeks tenaga kerja (ITK) divisi pisang di PG3 sebesar 2.08. Luas kebun yang ditanami pisang Cavendish adalah \pm 720 ha dengan pekerja sebanyak 1502 orang.

Kegiatan diperawatan terkadang waktunya molor dari jadwal yang dibuat. Hal ini karena tenaga kerja yang tidak mencapai kapasitas kerja yang ditentukan perusahaan. Beberapa penyebab tidak tercapainya kapasitas kerja ini adalah standar perusahaan yang cukup tinggi, ketersediaan bahan, dan alat kerja yang rusak, serta tidak efektifnya jam kerja. Berikut pengamatan prestasi kerja disajikan pada Tabel 7.

Tabel 7. Pengamatan prestasi tenaga kerja

\begin{tabular}{|c|c|c|c|c|}
\hline $\begin{array}{l}\text { Aktivitas } \\
\text { Perawatan }\end{array}$ & \multicolumn{2}{|c|}{$\begin{array}{c}\text { Standar } \\
\text { Perusahaan }\end{array}$} & $\begin{array}{c}\text { Prestasi } \\
\text { Kerja }\end{array}$ & $\begin{array}{c}\text { Persentase } \\
(\%)\end{array}$ \\
\hline $\begin{array}{l}\text { Pemangkasan } \\
\text { daun }\end{array}$ & 3000 & pohon & 1505.5 & 50.2 \\
\hline $\begin{array}{l}\text { Penghilangan } \\
\text { anakan }\end{array}$ & 1200 & pohon & 722.6 & 60.2 \\
\hline Pemupukan & 1.2 & ha & 0.9 & 75.0 \\
\hline $\begin{array}{l}\text { Penyemprotan } \\
\text { herbisida }\end{array}$ & 1 & ha & 0.6 & 60.0 \\
\hline $\begin{array}{l}\text { Penyemprotan } \\
\text { insektisida pada } \\
\text { daun }\end{array}$ & 1 & ha & 0.5 & 50.0 \\
\hline Suntik jantung & 130 & pohon & 87.6 & 67.4 \\
\hline Pembrongsongan & 130 & pohon & 58.0 & 44.6 \\
\hline DDF & 150 & pohon & 65.9 & 43.9 \\
\hline $\begin{array}{l}\text { Pemasangan sekat } \\
\text { buah }\end{array}$ & 80 & pohon & 30.0 & 37.5 \\
\hline
\end{tabular}

Data di atas adalah rata-rata dari 10 kali ulangan pengamatan. Berdasarkan data tersebut prestasi tenaga kerja masih dibawah standar perusahaan. Persentase terbesar adalah pemupukan sebesar $75 \%$ dan paling rendah adalah pemasangan sekat sebesar $37.5 \%$. Rata-rata persentase sebesar $54.3 \%$ yang menandakan pekerjaan dapat diselesaikan setengah dari target per hari.

Standar perusahaan untuk beberapa pekerjaan lebih tinggi apabila dibandingkan dengan yang ada di PT Perkebunan Nusantara VIII (PTPN VIII). Pekerjaan pembuangan anakan standar dari PTPN VIII adalah sejumlah 600 anakan (Artha, 2016). Sedangkan di PT GGP untuk pembuangan anakan adalah dihitung dari tanaman induk yang jumlahnya 1200 tanaman. Perbedaan standar ini dipengaruhi oleh bentuk kebun. Bentuk kebun PG3 lebih datar dari PTPN VIII dan penanaman pisang di PG3 dilakukan secara monokultur sedangkan PTPN VIII tumpangsari dengan teh. Prestasi kerja yang rendah dapat dipengaruhi oleh ketersediaan buah di kebun yang masih sedikit. Ketika buah yang ada di kebun sedikit standar pekerjaan akan diganti dengan sistem pencapaian luasan (cover block). Pengadaan bahan untuk perawatan yang terlambat akan membuat perawatan telat karena harus menunggu. Hal ini membuat kasi harus mensiasatinya dengan mengalihkan pada pekerjaan lain. Sebagai contoh apabila stok herbisida habis, pekerja akan dialihkan untuk 
pekerjaan penyemprotan insektisida atau sanitasi kebun. Selama ini pekerja membawa alat kerjanya sendiri dan bertanggung jawab atas kerusakan alat tersebut. Jadi ketika rusak pekerja harus menunggu perbaikan. Ada baiknya perusahaan menyiapkan beberapa alat kerja untuk pengganti. Alat ini dapat digunakan oleh pekerja selama alat kerja miliknya diperbaiki. Kurangnya pengawasan membuat jam kerja tidak efektif.

\section{KESIMPULAN}

Kegiatan penelitian secara umum memberikan keterampilan teknis dan manajerial tentang budidaya pisang Cavendish dan perawatan secara khusus. Aktivitas yang dapat menentukan kualitas buah adalah pemangkasan daun, penyutikan jantung, pembrongsongan, pembuangan bunga, pembuangan buah, pembuangan penghalang buah, dan pemasangan sekat buah. Pemberian pupuk ditujukan untuk mencukupi kebutuhan hara bagi pisang terutama hara makro. Penyakit pisang yang menjadi kendala di lokasi penelitian adalah black leaf streak (BLS) yang disebabkan oleh Mycosphaerella fijiensis dan banana freckle disebabkan oleh Guignardia musae. Kehilangan populasi untuk ekspor di tempat penelitian terbesar karena kondisi no functional leaf (NFL) karena Banana Freckle. Blok dengan kondisi NFL terbesar adalah blok 27A dengan jumlah 7420 tanaman. Perhitungan tenaga kerja berdasarkan luas kebun dibagi dengan standar kapasitas dikali jumlah hari kegiatan. Indeks tenaga kerja sebesar 2.08 .

\section{DAFTAR PUSTAKA}

Artha, L. 2016. Produksi pisang cavendish di kebun Cibungur, PTPN VIII, Sukabumi, Jawa Barat. [Skripsi]. Institut Pertanian Bogor. Bogor.

[BPS] Badan Pusat Statistik. 2016. Produksi pisang menurut provinsi tahun 2011-2015. http://www.pertanian.go.id/Data5tahun/pdfHORTI2016/2.2Produksi-\%20Pisang.pdf. [25 Desember 2016].
[Deptan] Departemen Pertanian. 2005. Prospek dan Arah Pengembangan Agribisnis Pisang. Badan Penelitian dan Pengembangan Pertanian Departemen Pertanian, Jakarta.

[Ditjenhorti] Direktorat Jenderal Hortikultura. 2016. Buku Saku Pisang Musa sp. Kementerian Pertanian, Jakarta.

[FAO] Food and Agriculture Organization. 2016. Banana facts and figures. http:/www.fao.org/economic/ est/estcommodities/bananas/bananasfacts/en/\#.WGOWX_mLTIU. [04 Januari 2017]

[Kementan] Kementerian Pertanian. 2014. Outlook Komoditi Pisang. Pusat Data dan Sistem Informasi Pertanian Sekretariat Jenderal Kementerian Pertanian, Jakarta.

Kurniawati, A., Kasutjianingati, M Bahrir. 2011. Pengaruh pembrongsongan terhadap kualitas serta tingkat serangan hama penyakit buah pisang tanduk (Musa parasidiaca Var. Typica, AAB Group). Dalam: S.W. Ardie, D. Sukma, L. Prabaningrum, T.K. Moekasan (eds). Seminar Nasional Perhimpunan Hortikultura Indonesia. Kemandirian Produk Hortikultura untuk Memenuhi Pasar Domestik dan Ekspor. Lembang, 23-24 November 2011.

Ngatoif. 2011. Pengaruh pemotongan bunga jantan terhadap produksi dan mutu buah pisang ambon (Musa parasidiaca var. sapientum L.). [Skripsi]. Institut Pertanian Bogor. Bogor.

[PKHT IPB] Pusat Kajian Hortikultura Tropika IPB. 2014. Teknologi Sehat Budidaya Pisang. Pusat Kajian Hortikultura Tropika IPB. Bogor.

[Pusdatin] Pusat Data dan Sistem Informasi Pertanian. 2014. Buletin Konsumsi Pangan. Pusat Data dan Sistem Informasi Pertanian. 5(3):38. 